\title{
PATOGENISITAS BAKTERI LAYU PISANG (RALSTONIA SP.) PADA BEBERAPA TANAMAN LAIN
}

\author{
Titik Nur Aeny ${ }^{1}$
}

\begin{abstract}
Pathogenicity of banana wilt bacteria (Ralstonia sp.) on several other plants. This experiment was conducted to investigate the pathogenicity of bacterial wilt of banana pathogen (Ralstonia sp.) isolated from infected plants in Lampung on tomato, chili pepper, eggplant, and ginger. The experiment was conducted in Laboratory of Plant Protection Department, Faculty of Agricultural University of Lampung, from May 1999 to February 2000. Treatments in this experiment were arranged in a completely randomized design with four replications. The treatments were tomato, eggplant, chili pepper, and ginger. Banana was used as the control. The results of this experiment showed that up to 30 days after inoculation, the bacteria isolated from banana found in Lampung was not able to cause symptom on tomato, chili pepper, eggplant, nor ginger. However, this bacteria caused wilting on banana eight days after inoculation; the incubation period of this bacteria on banana was eight days.
\end{abstract}

Kata kunci: penyakit layu bakteri, Ralstonia (Pseudomonas) sp., patogenisitas, tanaman inang, ras

\section{PENDAHULUAN}

Di Indonesia, hingga saat ini penyakit layu bakteri tersebab Ralstonia (Pseudomonas) solanacearum masih merupakan salah satu penyakit yang sangat penting pada berbagai jenis tanaman hortikultura. Telah sering dilaporkan bahwa bakteri ini mempunyai banyak tanaman inang, meliputi tomat, kentang, terung, cabai, buncis, kacang panjang, jahe, dan pisang. Khusus pada tanaman pisang, penyakit layu bakteri yang ditemukan di Jawa dikenal dengan sebutan penyakit darah, dan bakteri penyebabnya disebut sebagai blood disease bacterium (BDB) (EdenGreen \& Sastraatmadja, 1990). Isolat bakteri penyebab penyakit layu pada pisang di Lampung mempunyai karakteristik yang sangat mirip dengan BDB, tetapi agak berbeda dengan ciri-ciri yang dimiliki isolat $P$. solanacearum sehingga diajukan sebutan Ralstonia sp. (Mujim et al., 1999).

Berdasarkan jenis tanaman inangnya, bakteri layu dikelompokkan menjadi lima ras; sedangkan berdasarkan sifat-sifat kataboliknya dibedakan menjadi lima biovar (Goto, 1992; Seal et al., 1993). Ras tertentu hanya dapat menyerang tanaman atau kelompok tanaman tertentu. Misalnya, ras 1 dilaporkan hanya menyerang tanaman solanaceae, ras 2 hanya dapat menyerang tanaman pisang dan pisang-pisangan, atau ras 3 hanya dapat menyerang tanaman jahe. Akan tetapi, Dikin et al. (1997) melaporkan bahwa isolat bakteri $P$. solanacearum yang berasal dari pisang di Lampung dapat menyerang tanaman pisang, heliconia, dan jahe. Hal ini menunjukkan bahwa bakteri yang ditemukan di Lampung agak berbeda dengan yang ditemukan sebelumnya di tempat lain. Meskipun demikian, belum diketahui apakah isolat bakteri layu yang ada di Lampung juga dapat menyerang jenis-jenis tanaman lainnya.

Karakteristik isolat bakteri dari Lampung yang lebih mirip dengan BDB dibandingkan dengan P. solanacearum (Mujim et al., 1999), diduga dapat mempengaruhi patogenisitas dan virulensi bakteri tersebut. Dengan demikian, dikhawatirkan tanaman yang dapat diserangnya tidak terbatas pada pisang saja melainkan juga tanaman-tanaman penting lainnya. Mengingat bakteri $R$. solanacearum merupakan bakteri tular tanah yang mempunyai banyak tanaman inang dan mampu bertahan lama di dalam tanah meskipun tanpa tanaman inang (Goto, 1992), maka lahan yang sudah terinfestasi oleh bakteri tersebut, baik yang berasal dari pertanaman pisang maupun dari bekas pertanaman lain yang juga menjadi inangnya, akan memungkinkan timbulnya kembali penyakit layu bakteri pada tanaman pengganti berikutnya (Aeny et al., 1997).

Penelitian ini dilakukan untuk menyelidiki apakah isolat bakteri layu pada pisang di Lampung dapat menyerang tanaman tomat, cabai, terung, dan jahe. Hal ini sekaligus untuk menjawab pertanyaan apakah lahan bekas pertanaman pisang memungkinkan

1 Dosen Jurusan Proteksi Tanaman, Fakultas Pertanian, Universitas Lampung 
untuk ditanami dengan tanaman-tanaman lain seperti yang tersebut di atas.

\section{BAHAN DAN METODE}

Percobaan dilaksanakan di Laboratorium Jurusan Proteksi Tanaman Fakultas Pertanian Universitas Lampung, pada bulan Mei 1999 sampai dengan Pebruari 2000.

Bahan-bahan yang diperlukan pada percobaan ini ialah inokulum (ooze) bakteri penyebab penyakit layu pisang, bibit pisang varietas Barangan, bibit tanaman tomat, cabai, terung, dan jahe, air steril, dan alkohol 70\%. Alat-alat yang diperlukan adalah suntikan (disposable syringe), pisau, polybag, gunting, label, dan alat-alat untuk perawatan tanaman.

Percobaan ini menggunakan Rancangan Acak Lengkap dengan 4 ulangan. Perlakuan terdiri atas empat jenis tanaman inang yang diuji, yaitu: tomat (P1), terung (P2), cabai (P3), dan jahe (P4). Sebagai pembanding, digunakan tanaman pisang. Pada percobaan uji patogenisitas ini inokulum bakteri yang digunakan adalah ooze bakteri yang dikumpulkan dari tanaman sakit di lapang. Virulensi bakteri secara invitro diuji dalam media agar tetrazoliumchlorida (agar TZC).

Semua tanaman inang yang diuji adalah tanaman yang masih dalam fase vegetatif, yang berumur 2 - 3 bulan. Bibit tanaman tersebut masing-masing ditanam dalam polibeg berkapasitas $10 \mathrm{~kg}$. Setiap perlakuan terdiri atas empat tanaman dan masingmasing diulang sebanyak empat kali, sehingga setiap satu satuan percobaan terdiri atas enambelas tanaman. Pada setiap tanaman diinokulasikan sebanyak $5 \mathrm{ml}$ suspensi bakteri. Inokulasi secara buatan dilakukan dengan cara menyuntikkan suspensi bakteri pada pangkal batang tanaman yang berdekatan dengan permukaaan tanah.

Patogenisitas bakteri didasarkan pada kemampuan bakteri yang diinokulasikan dalam menimbulkan gejala pada tanaman yang diuji. Selain itu dicatat juga masa inkubasi patogen dan intensitas penyakit pada setiap tanaman inang. Masa inkubasi merupakan periode waktu sejak saat inokulasi sampai timbulnya gejala pertama, sedangkan intensitas penyakit dihitung untuk mengetahui persentase serangan pada masing-masing tanaman inang. Pengamatan terhadap perkembangan gejala dilakukan seminggu sekali sampai tanaman kontrol mati.

\section{HASIL DAN PEMBAHASAN}

Dari hasil penelitian ini dapat diketahui bahwa isolat bakteri penyebab penyakit layu (Ralstonia sp.) pada pisang di Lampung tidak dapat menimbulkan gejala layu pada tanaman tomat, cabai, terung, maupun jahe (patogenisitasnya negatif). Akan tetapi, bakteri tersebut dapat menimbulkan gejala layu pada tanaman pisang (Tabel 1).

Tabel 1. Patogenisitas bakteri Ralstonia sp pada beberapa tanaman

\begin{tabular}{lc}
\hline Jenis Tanaman & Patogenisitas \\
\hline Tomat & negatif \\
Cabai & negatif \\
Terung & negatif \\
Jahe & negatif \\
Pisang & positif \\
\hline
\end{tabular}

Supriadi et al. (2000) melaporkan bahwa bakteri penyebab layu pada tanaman jahe dapat menyerang tomat, terung, dan beberapa jenis gulma tetapi tidak dapat menimbulkan gejala layu pada kacang tanah, nilam, cabai keriting, maupun pisang. Hal ini nampaknya berkaitan dengan adanya perbedaan antara ras bakteri yang menyerang tanaman pisang dengan rasras lain yang menyerang jahe, tomat, terung, maupun cabai. Informasi ini mungkin juga dapat menunjukkan bahwa tanaman-tanaman tersebut mempunyai ketahanan yang berbeda-beda terhadap ras-ras tertentu bakteri layu. Dengan demikian, mungkin saja bakteri tersebut dapat menginfeksi beberapa jenis tanaman tetapi tanpa menimbulkan gejala (Seal et al., 1993).

Dari hasil penelitian ini dapat juga dilaporkan bahwa masa inkubasi bakteri Ralstonia sp. pada tanaman pisang adalah delapan hari, sedangkan masa inkubasi bakteri pada jahe, tomat, cabai, maupun terung tidak dapat diukur karena gejala layu pada tanaman tersebut tidak muncul sampai dengan 30 hari setelah inokulasi.

Pada akhir percobaan, batang tanaman pisang, tomat, cabai, terung, dan jahe dipotong lalu dibuat irisan melintang dan irisan membujur. Pada rimpang jahe juga dilakukan hal yang sama. Dari kedua macam irisan tersebut dapat diamati adanya perubahan warna yang 
kecoklat-coklatan serta kebasahan pada batang pisang, batang jahe, dan rimpang jahe. Perubahan warna pada batang dan rimpang tanaman tersebut ternyata berkaitan dengan tumbuhnya koloni bakteri di sekitar irisan batang dan rimpang tersebut yang diinkubasi pada media agar sucrose peptone. Koloni bakteri yang tumbuh tersebut mempunyai ciri-ciri yang menyerupai koloni bakteri Ralstonia sp. seperti yang dilaporkan oleh Mujim et al. (1999).

\section{KESIMPULAN}

Dari hasil penelitian ini dapat disimpulkan bahwa patogenisitas isolat bakteri penyebab penyakit layu pada tanaman pisang (Ralstonia sp.) di Lampung adalah positif pada tanaman pisang tetapi negatif atau tidak dapat menyebabkan penyakit layu pada tanaman tomat, terung, cabe, maupun jahe. Masa inkubasi bakteri pada tanaman pisang adalah delapan hari.

\section{SANWACANA}

Ucapan terima kasih saya sampaikan kepada Proyek Pengkajian dan Penelitian Ilmu Terapan-DP3M Dirjen Dikti yang telah memberi dana penelitian. Ucapan terima kasih juga saya sampaikan kepada. Marolop Th. Sinaga, S.P. atas bantuannya selama pelaksanaan penelitian ini, dan Dr. Subli Mujim, Ir. Efri, M.S., serta Dr. Cipta Ginting atas saran-sarannya dalam perbaikan tulisan ini.

\section{DAFTAR PUSTAKA}

Aeny, T. N., S. Mujim, \& Efri. 1997. Intensitas penyakit layu bakteri (Pseudomonas solanacearum) pada beberapa kultivar pisang. Hlm: 467- 470 Prosiding
Seminar Nasional dan Kongres Fitopatologi, Palembang, 27-29 Oktober 1997.

Dikin, A., F. Kordina, \& Hermawan. 1997. Perbedaan isolat bakteri penyebab penyakit layu pisang di Lampung dan Jawa. Hlm. 407-410 dalam: Risalah Kongres Nasional XIII dan Seminar Ilmiah, Perhimpunan Fitopatologi Indonesia. Mataram, 25-27 September 1995.

Eden Green, S. J. \& H. Sastraatmadja. 1990. Blood disease present in Java. FAO Plant Protection Bulletin 38: $49-50$.

Goto, M. 1992. Fundamentals of Bacterial Plant Pathology. Academic Press Inc., San Diego.

Mujim, S., T. N. Aeny, C. Ginting, S. Kusumoto, Y. Takikawa, S. Tsuyumu, \& T. Tsuge. 1999. Studies on bacterial wilt of banana in Lampung, Indonesia: Identification of the causal agent and screening of banana cultivars for disease resistance. Pages 527-532 in: Ginting C. et al. eds. International Seminar "Toward Sustainable Agriculture in Humid Tropics Facing $21^{\text {st }}$ Century” Bandar Lampung Indonesia.

Seal, S.E., L.A. Jackson, J.P.W. Young, \& M.J. Daniels. 1993. Differentiation of Pseudomonas solanacearum, Pseudomonas syzygii, Pseudomonas pickettii and the Blood disease bacterium by partial $16 \mathrm{~S}$ rRNA sequencing: construction of oligonucleotide primers for sensitive detection by polymerase chain reaction. Journal of General Microbiology 139: 1587 1594.

Supriadi, K. Mulya, \& D. Sitepu. 2000. Strategy for controling wilt disease of ginger caused by Pseudomonas solanacearum. Jurnal Litbang Pertanian 19(3): 


\begin{tabular}{|ll|}
\hline $\begin{array}{l}\text { Tabel 1. Patogenisitas bakteri Ralstonia sp. pada } \\
\text { beberapa tanaman inang }\end{array}$ \\
\hline Tanaman Inang & Patogenisitas \\
\hline Tomat & negatif \\
Cabai & negatif \\
Terung & negatif \\
Jahe & negatif \\
Pisang & positif \\
\hline
\end{tabular}

